\title{
NEW LIGHT ON JOHN WOODALL, SURGEON AND ADVENTURER
}

\author{
by
}

\author{
JOHN H. APPLEBY*
}

AT THE end of a definitive article about John Woodall, first Surgeon General of the East India Company, Sir Geoffrey Keynes wrote:

This account of Woodall's career and writings has, it is hoped, demonstrated that his place in medical history is of great importance. He was one of the earliest medical administrators as organiser of a rudimentary medical service for ships at sea. He was the first medical writer to provide a good text-book designed for the instruction of the younger men in the service. He was an innovator of the safe and humane treatment of gangrenous limbs. He was the inventor of the trephine, used by generations of surgeons until quite recent times. Above all he was the first medical man to write a clear account of scurvy, the scourge of the early voyagers, and to insist on the effectiveness of lemon juice in its prevention and treatment. ...

Although Keynes and, earlier, Sir Norman Moore ${ }^{2}$ drew attention to Woodall's mercantile activities, several primary sources of information have recently emerged which reveal them to have been far more extensive than imagined, and which shed light on John Woodall and his career. For example, contrary to the traditional dating of his birth to 1556-7, the documents of two legal cases at which Woodall gave evidence in 1621 and 1638 prove that he was born in $1570 .{ }^{3}$

As to Woodall's death, an unusual set of circumstances has obscured the appearance of his will, which was proved in the Prerogative Court of Canterbury (PCC) on 6 August 1643 at Oxford.4 First, copies of the sole printed means of reference to Oxford wills of this period, Abstracts of Probate Acts in the Prerogative Court of Canterbury, edited by John Matthews and George F. Matthews, are rare today, as they were issued to subscribers only. A copy at the Public Record Office contains Woodall's name with the reference "will proved at Oxford in August [1643]." The reason why probate business was transacted from Oxford instead of from London is that in May 1643 Dr. William Merrick, Judge of the PCC, went to Oxford taking the court's seal with him, and proceeded to prove wills and grant administrations from there. In November 1643 Parliament declared Merrick's jurisdiction invalid

\footnotetext{
*John H. Appleby, M. A., Ph.D., 51 College Road, Norwich, Norfolk NR2 3JP.

'Sir Geoffrey Keynes, 'John Woodall, surgeon, his place in medical history', J. R. Coll. Physns Lond., 1967, 2: 33.

2 Dictionary of national biography (hereinafter DNB), vol. 62, pp. 382-383.

${ }^{3}$ Public Record Office (hereinafter PRO): Town Depositions, (a) C24/473; (b) C24/629/23 and 32. Moore queries 1556 as Woodall's birth date, while Keynes suggests it was $c$. 1556-7.

4 PRO: PCC Probate 10/639, August 1643 (5 ff.). John Woodall's will, made 5 April 1643 and proved 6 August 1643 at Oxford.
} 
and appointed Sir Nathaniel Brent as judge of the Prerogative Court in London. Second, and following on from this situation, there is a gap in the London Registers (or transcripts) of Wills and Act Books (day-by-day accounts of the official grants of probate). Consequently, as there are no Registers of Wills from Oxford, recourse must be had to the original wills. Third, consulting original wills from Oxford poses no problems, but their listing at the Public Record Office, including the entry for Woodall, has been inaccurate in many cases, which is why searchers have failed to trace Woodall's will before. Further, it is possible that the wrong probate date was recorded for Woodall's will, which should have read 6 September, instead of 6 August 1643. Richard Smyth noted that "Old Mr Woodhall, ye surgeon" died on 28 August $1643,{ }^{3}$ and the register of St. Benet Fink's church in London indicates that he was buried there on 31 August. ${ }^{6}$ When Woodall drew up his will, he expressed the desire to be buried at St. Benet Fink's, where his wife, Sarah Henchpole, whom he married at St. Peter's, Cornhill, on 18 December $1603,{ }^{7}$ had been buried on 9 September 1641. The registers of both churches together give the christenings of nine children, three of whom survived their father. ${ }^{8}$ Presumably Margaret Eaton, the eldest daughter and executrix of his will, was baptized elsewhere.

Woodall bequeathed to his eldest son, John, "three of my best lancetts tipped all wth silver" and "a silver salvatorie and a competent sett of silver instruments therein used." These, together with the "old plaister boxe of silver and ebony wth all such instruments as shalbe found therein," which went with their contents to his son Thomas, are clearly described and depicted in John Woodall's book The surgeons mate. Thomas Woodall was made free of the Barber-Surgeons' Company by patrimony on 4 September 1639.10

A surgeon in Woodall's day ranked below a physician in status, and the College of Physicians of London was able to restrict his functions. An example of this was that surgeons were unable to prescribe medicines, as only members of the College were qualified to do so. In addition, it was enacted that no major operations - those involving danger to life - should be attempted without a physician being present. As may well be visualized, these and other restraints on surgical practice led to repeated confrontations between surgeons and physicians. According to Moore, Woodall was admitted a Barber-Surgeon in 1599, but in fact the Company's records show that "John Udall", apprenticed to Thomas Hobbins, received his freedom on 24 March

\footnotetext{
'Sir Henry Ellis (editor), The obituary of Richard Smyth, London, Camden Society, 1849, vol. 44, p. 20.

'(a) Guildhall Library: MS. 4097 (unfoliated), "Buryalls". (b) The church of St. Benet Fink, on the south side of Threadneedle Street in Broad Street, was pulled down in 1842-4 to make way for the New Royal Exchange, the parish united with St. Peter-le-Poer, and the monuments removed there: Henry A. Harben, A dictionary of London, London, Herbert Jenkins, 1918, p. 66. (c) In its turn, St. Peter-le Poer was merged with St. Michael's, Cornhill, and no memorial to Woodall has been traced: Letter, 22 April 1980, from Canon Norman Motley, incumbent of St. Michael's.

'Society of Genealogists, Archives: Boyd's Citizens of London, London, 1939, no. 6415.

8 Op. cit., note 6 (a) above.

' John Woodall, The surgeons mate or military and domestique surgery, London, R. Young for $\mathrm{N}$. Bourne, 1639, first five unpaginated sides, and pp. 16-20.

${ }^{10}$ Guildhall Library: MS.5265/1, f. 93 , 'Register of admissions to the freedom of the Worshipful Company of Barber Surgeons of London. 1522-1664.'
} 
$1600 / 1 .^{11}$ This probably means that he was admitted to the freedom of the City of London (as attested by his will) at the same time, although, since no records exist for the period before 1681 , it cannot be verified. ${ }^{12}$

A lengthy interval passed before "Mr. Udall" was elected to the Barber-Surgeons' court of assistants on 13 January 1618/9. He made an appearance as a member of the court on 2 March, was present unproclaimed on 7 May (as "Mr. Woodall"), and attended regularly thereafter, the two names alternating at first but soon giving way to the one by which he was best known. ${ }^{13}$ In 1625 he.was elected Junior Warden, in 1627 Middle Warden, in 1629 Upper Warden, and in 1633 Master. ${ }^{14}$ However, Woodall's association with the Barber-Surgeons was by no means without controversy. On at least two occasions complaints were levelled against him for his abusive language. In 1620 only his abject apology prevented his place as an assistant from being sequestered, "for that Mr. Udall at a publique dinner made in this hall dyd gyve unsemely words. ... And for that likewise the said Mr. Udall did formerly take Mr. [Joseph] Ffenton at a Court wth unsemely speeches...."; 15 while, in January 1626, “... this Courte takeing into their consideracions the unseemely carriage and ill language used by John Woodall to Mr. Warden Thornebury in Sr. John Wolstenholme's house about the imprest of his man William Hollidaye for the kings service was by this Courte censured to paye his fine. ..."16 A further dispute resulted in Woodall being fined for "ill words" and for taking away one of the surgeon John Quince's patients. In August 1629 Woodall paid a fine of $£ 10$ "for not serveing the upper wardenshipp of the livery of this companie," for which dereliction of duty he was replaced, since strict attendance was required. ${ }^{17}$ Nonetheless, he was a useful and active member of his confraternity and left it $£ 5$ for an annual "repast". Other sources make it clear that the six apprentices, mentioned between 1622 and 1634 in the company's register of freedoms as having served under Woodall, represent but a small proportion of those apprenticed to him..$^{18}$

When the East India Company was formed into a joint-stock business in 1612 , Woodall was appointed its first Surgeon General. It was an appropriate choice. He had begun his career as an army surgeon in Lord Willoughby's regiment in 1591, lived and worked in Germany for eight years, travelled extensively abroad and, on his return, settled in Wood Street, London, where he worked hard with his cure during the plague of 1603 . He had also been sent to Poland on public business early in James I's reign. ${ }^{19}$ A document describes him as "a surgeon in the army in 1612" - the same year in which he was appointed Surgeon General to the East India Company. ${ }^{20}$ At this

\footnotetext{
"Ibid., f. 37v, and $D N B$, op. cit., note 2 above. "Udall" was the name with which Woodall applied for matriculation of his coat of arms (The visitation of London, London, Harleian Society, 1883, vol. 2, p. 365).

12 Letter from the Keeper of MSS., Guildhall Library, 29 February 1980.

${ }^{13}$ Guildhall Library: MS. 5257/4, ff. 321-3, etc., Court minutes book of the Barber-Surgeons' Company (1607-21).

${ }^{14}$ Guildhall Library: MS. 5257/5, Court minutes book of the Barber-Surgeons' Company (1621-51).

15 Op. cit., note 13 above, f. 328 (21 October 1620).

16 Op. cit., note 14 above, f. 42 (19 January 1625/6).

17 Ibid., ff. 8, 24, 38-40; and f. 96 (22 August 1629).

$18 \mathrm{Op}$. cit., note 10 above.

19 DNB, op. cit., note 2 above.

${ }^{20}$ Rev. A. H. Johnson, The history of the worshipful company of the Drapers of London, Oxford, Clarendon Press, 1922, vol. 4, p. 86.
} 


\section{John H. Appleby}

stage in his career, as will be seen later on, Woodall had invested considerable sums of money in overseas companies, so that it is fair to assume he owed his appointment as Surgeon General as much to his wide experience and organizational ability as a military surgeon and merchant, as to influential contacts.

Woodall's career as the East India Company's Surgeon General is amply recorded in the calendars of colonial state papers and the Company's Court minutes, but several aspects of it need to be accentuated and clarified. In his will, Woodall asks for an inventory to be made of his estate, consisting of ". . . mony plate debts beddinge lynnen gowns and goldstuffs leases adventures wages sallery or otherwise howsoer and as may be made manifest by the books of accompte kept in the East India House and by some papers of my owne or by any other faire wayes or meanes whatsoer..." The details were very likely kept in the Company's "Personal Accounts". Woodall's name is listed in an index to them for the period between 1631 and 1642, but unfortunately no information on what was in the account itself survives. ${ }^{21}$

When the East India Company was organized on a joint-stock basis in 1612, shareholders received Bills of Adventure in return for their subscriptions, entitling them, pro rata their contribution, to a share in the Company's profits. Although the extent of Woodall's participation in the first joint stock (his "adventure", or form of investment) is not clear, in March 1620 John Moseley transferred to him $£ 1,000$ of adventures in the Company's second joint stock, a quarter of which was made over to George Mynn in 1630.22 Margaret Eaton, Woodall's daughter and executrix, was paid £26 13s. 2d. - the division on her father's adventure - in February 1644, and she transferred $£ 100$ to James Martin. ${ }^{23}$

On his appointment as Surgeon General, Woodall drew up regulations for the Company's surgeons and compiled lists of instruments and medicines for their chests. Indeed, it was chiefly for the benefit of the surgeons that he incorporated this preliminary work in his book, published in 1617, entitled The surgion's mate, or a treatise discovering faithfully the due contents of the surgion's chest. ${ }^{24}$ But company policy changed: from 1620 and for several years surgeons, physicians, and apothecaries all had a say in the contents of the surgeons' chests. To begin with, the arrangement appeared amicable enough, with Woodall and an apothecary looking after the surgical side, and Dr. Henry Atkins, F.C.P., ${ }^{25}$ ("one of the company, a very sufficient and honest man and great adventurer") examining the "physical things". But on 18

\footnotetext{
${ }^{21}$ India Office Library: L/AG/1/1: 'A comprehensive index to the home ledgers of the East India Company, compiled by S. J. McNally, typescript, [n.d.], Part 1, 'Personal accounts', p. 2. The volume to which McNally's Index refers is a missing "Alphabet[ical index] to ye lidger of ye 3d Ioynt Stock of ye March[an]ts of Londo[n] trading the East Indies" (India Office Records: H/1, ff. 1-43). This lost ledger probably recorded general, rather than specifically stock, details since the index refers to ships, stores, and miscellaneous accounts as well as to personal names. Letter from Mrs. S. R. Hofmann, India Office Library and Records.

22 William Noël Sainsbury (editor), Calendar of state papers, colonial series, East Indies . . (1617-21), London, 1870, p. 408; and ibid., 1630-34, p. 109.

${ }^{23}$ Ethel Bruce Sainsbury (editor), $A$ calendar of the court minutes of the East India Company. $1644-1649$, Oxford, 1912, p. 9.

${ }^{24} \mathrm{DNB}$, vol. 62, p. 382 .

${ }^{2 s}$ Ibid., vol. 2, p. 219.
} 


\section{New light on John Woodall, surgeon and adventurer}

February 1620, new instructions were given for the chests to be viewed by Drs. Torye and John Raven (F.C.P. and physician to the queen), ${ }^{26}$ Woodall having provided the contents; and at the end of 1621 it was decided that all samples for the surgeons' chests should be purchased from a single apothecary nominated by the Company. ${ }^{27}$ Despite this initially workable relationship, Woodall's position as Surgeon General became so untenable, caught up in the cross-fire of others' conflicting interests, that he made up his mind in July 1623 to force the issue of who provided what by petitioning against anyone else being permitted to supply the surgeon's chest for the Charles. After discussion, the Company resolved that a trial medicine chest for 100 men, with prices marked, should be provided - in other words, that it should be open to competition. Two months later Dr. Atkins and Dr. Thomas Winston, another eminent F.C.P., produced their surgeon's chest for the Charles, as did Woodall. Objections, unspecified in the Court minutes but presumably from the physicians, were made against Woodall, who was risking his career for greater autonomy, but the Company refused "to displace an old servant before they have heard him," and instead ordered the Master and Wardens of the Barber-Surgeons, as well as certain physicians, to view and give their opinions of both chests. A few days after this, having had their chest inspected and passed by the College of Physicians, Atkins and Winston expressed their reluctance to come into conflict with surgeons, "as a thing ill becoming their calling." 28 The Court overcame this obstacle by decreeing on 12 September that both the surgeons' chests were to be examined by Dr. Thomas Moundeford (president of the College of Physicians), Dr. Hudson, and Dr. Theodore Mayerne, in the combined presence of the Masters and Wardens of the Apothecaries and Barber-Surgeons' Companies and such of the East India Company's surgeons, returned from the Indies, who could be found to be present. ${ }^{29}$ Thus all parties were fairly represented, but the immediate result of the competition is not known.

Any resentment that Woodall, as Surgeon General of the East India Company, had felt at interference by physicians in supplying surgeons' chests, surfaced again in February 1624 when, with characteristic combativeness, he suppressed an order for the examination by Dr. Atkins of surgeons designated for the fleet. He found an ally in the Deputy Governor who informed the Court that he had "spoken with a learned physician, who wondered that physicians should taken upon them to set down surgeons' proportions, the same not being proper to their art, save only for matter of physic; it was therefore thought fit that in matter of physic they consult with

\footnotetext{
${ }^{26}$ William Munk, The roll of the Royal College of Physicians of London, London, Royal College of Physicians, 1878, vol. 1, p. 168.

${ }^{27}$ E. B. Sainsbury (ed.), op. cit., note 23 above, p. 350 (16 February 1620); ibid., p. 351 (18 February 1620); ibid., p. 499 (26-29 December 1621).

${ }^{28}$ For Winston see $D N B$, vol. 62, p. 212 . This reluctance is understandable in the light of Drs. Winston and William Clement having proceeded earlier that same year to Surgeons' Hall to examine naval surgeons, but being refused admittance. Fenton had been summoned to answer for this affront, but no satisfaction was given. On 25 June the College had appointed a committee on surgeons and apothecaries illicitly practising medicine, but nothing had been reported against the surgeons: Sir George Clark, $A$ history of the Royal College of Physicians of London, Oxford University Press, 1964, vol. 1, p. 242.

${ }^{29}$ E. B. Sainsbury (ed.), op. cit., note 23 above, 1622-1624, London, 1878, pp. 122, 149, 150, 151.
} 


\section{John H. Appleby}

physicians and for surgery the surgeons give satisfaction to the committees." ${ }^{30}$ Once again Woodall appears to have had his way, though it was not until five years later, in 1629 , that a final solution was found to the vexed problem of who supplied the contents of the surgeons' chests: "The Surgeon's chest of the London having been viewed by the Surgeon that goes on the voyage and reported exceeding good, it was conceived that the Company might save the charge they were wont to give to those doctors and surgeons, whose names they entreated in this behalf, and it was resolved to rely on the honesty of Woodall and the judgment of the Surgeon that examined them." ${ }^{11}$

These two episodes, the provision of surgeons' chests and the examination of surgeons, clearly illustrate the friction and confusion existing for many years between the College of Physicians, the Barber-Surgeons, and the Apothecaries. Woodall also contributed to one other aspect of naval medicine. Keynes rightly stressed the particular importance of Woodall's as the best early published medical account of the use of citrus fruits to combat scurvy. ${ }^{32}$ Some credit should be given as well to Woodall's perspicacity when the Court of the East India Company, acting on his advice and that of a naval surgeon called Ralph Harris, gave orders in March 1627 to Richard Mountney, "husband" or treasurer, to buy three hogsheads of red wine for their ships, as they had been informed that "red ioyne is very usefull and Phisicall for men sicke of ye fflux" (dysentery). ${ }^{33}$

Woodall was also responsible for the health of the Company's saltpetre refiners. Some background information is necessary. The East India Company was an important customer for saltpetre, the major ingredient in the manufacture of explosives. As India was fast becoming the main source of this commodity and its bulk made it expensive to import, the Company was licensed in 1626 to make powder for its own needs, initially near Windsor Forest and then at Chilworth, not far from Guildford. The diarist John Evelyn, whose family had jealously guarded since the Armada their monopoly to make explosives, complained loudly about this infringement of his patent. A restraint was placed upon the Company lasting until July 1635 , when it was lifted and the Company produced powder for their own needs and for the king's use. ${ }^{34}$ However, it would seem that the Company manufactured explosives before this date, for in April 1633 Woodall reported that the sickness of their saltpetre refiners was caused by their coming "fasting" to work in the mornings. He proposed that the Court should allow them some "hott cawdles" to eat before they began work, "to keepe out the steame and smoake wch otherwise will gett into their stomaches, and in short time kill them their bodies being already shrunk \& much impayred." (In The surgeons mate Woodall prescribes a "comfortable Caudle made with some Wines, Spices, Sugar, and the yolk of an egge" as part of the treatment for sailors ill with scurvy.) The Court recommended that he prepare whatever breakfasts he should

\footnotetext{
${ }^{30}$ Ibid., pp. 244-245 (9 February 1624); and see p. 243 (3 February 1624 - examination of surgeons by physicians).

${ }^{31}$ Ibid., 1625-1629, London, 1884, p. 633 (25 February 1629).

${ }^{32}$ Keynes, op. cit., note 1 above, p. 33. See also D. McDonald, 'Dr. John Woodall and his treatment of the scurvy', Trans. R. Soc. trop. Med. Hyg., 1954, 48: 360-365.

${ }^{33}$ India Office Library Records: MS. B/11 (Court Book 9), f. 461, 7 March 1626/7.

${ }^{34}$ E. B. Sainsbury (ed.) op. cit., note 23 above. Introduction by William Foster, pp. xxxiii-xxxiv.
} 
think fit to promote their health and to prevent the sickness for a month or two. Mountney was required to cost the refining process so that the Court could decide whether to sell the saltpetre unrefined or to continue refining it. ${ }^{35}$ Whether this brought any improvement in the condition of the refiners is not recorded.

A good deal of Woodall's time as Surgeon General was taken up by duties in a dockside hospital used by the East India Company at Blackwall (now Poplar). The Company's dockyard there covered ten acres and included its own almshouses. Woodall petitioned the Company for a room in which to dress his patients at Black wall in $1617 . .^{36}$ From these humble origins this dockside first-aid centre developed into a kind of small hospital where emergency operations were carried out. Short-term treatment there became quite extensive from at least 1624 , as is plain from Woodall's petitions and the payments he received for his services - so much so, that he was obliged to request an allowance from the Company for a surgeon to live at Blackwall and to attend the yard and ships. ${ }^{37}$ His retrospective supplication for 1633 shows that in the past three years he had "... cured over 50 people, many of great diseases such as broken legs, arms, skulls, bones out of joint, and other great wounds and bruises, and disbursed mony for their diet, paid women to attend them, and otherwise put to charge by water and land and carrying them to hospitals and curing them." The Court awarded him $£ 50 .{ }^{38}$

The last recorded connexion between Woodall and Blackwall is on 8 May 1640, when he applied to the East India Company for wages which had been withheld from him since December 1635, pointing out that he had cured over 50 people since then and written "a booke of chirurgery for the good of the East India voyage." 39

Woodall worked in three other London hospitals. That he treated patients in Christ's Hospital is evidenced by the following entry in the East India Company's Court Book for 1642:

The Court was made acquainted this day that $\mathrm{Mr}$ Woodall had formerly the old Chirurgery chests returned and the potts, glasses and instruments for which hee allowed the Compie: the price of their cost, as alsoe that hee had all the old salves remayninge and that they are denyed him. The Court called him in and demanded of him whether hee did not boyle the salves againe, and soe make the Company pay for them a second tyme, the which upon his reputacion hee utterly denyed, But confessed hee made some use of them in Christ's Hospitall for the cureing of poore people there. The Court rested very well satisfyed with this answeare and did order that Mr Woodall should have the chests potts instruments \& salves in the manner hee hath formerly received the same... .

Woodall was elected surgeon to St. Bartholomew's Hospital on 19 January 1616, a position he retained till his death. His salary was $£ 30$ per annum, and he attended every Monday and Thursday. ${ }^{41}$

${ }^{35}$ Ibid., p. 398; and India Office Library Records: MS. B/15; Woodall, The surgeons mate, 1653, p. 164.

${ }^{36}$ W. N. Sainsbury (ed.), op. cit., note 22 above, p. 408; and ibid., 1630-1634, London, 1892, p. 109.

${ }^{37}$ (a) Ibid., 1625-1629, London 1884, p. 348; (b) ibid., 1630-1634, London, 1892, p. 94.

38 Ibid., p. 497.

${ }^{39}$ E. B. Sainsbury (ed.), op. cit., note 23 above, 1635-1639, Oxford, 1903, p. 40.

${ }^{40}$ India Office Library Records: MS. B/20 (Court Book 18), f. 237, 9 November 1642.

${ }^{\prime \prime}$ Norman Moore, The history of St. Bartholomew's Hospital, 2 vols., London, Pearson, 1918, vol. 2, pp. 810-816. Moore writes that Woodall was the "most noteworthy man on the surgical staff" when Harvey served there as physician. 


\section{John H. Appleby}

The other hospital at which Woodall is known to have been a surgeon was Thomas Sutton's Hospital at the Charterhouse, which originally took eighty gentlemen pensioners. ${ }^{42}$ The Charterhouse Assembly Orders for 19 July 1614 convey the decision of the Governors to elect Dr. Thomas Barker the hospital's first physician, and "Item we doe appoynte and constitute Mr. John Woodall to be the Chirurgion of the sayd Hospital his ffee $\mathrm{x} 1 \mathrm{p}$ Annum to be payde quarterly and his Chamber to be appoynted by the Surveyor." A subsequent entry for 28 June 1619 runs: "Wee doe order constitute and ordeyne that John Woodall Chirurgion of the Hospitall shall have those roomeths and chirurgery houses as is appointed for him by the surveyor of the Hospitall and furniture to them as is fyttinge for such an Officer to have yearely paide unto him his ffee of tenne poundes and also the allowance of $x x 1$. appointed for Chirurgery soe as he putt in security not to chardge the house with any more then $\mathrm{xx} 1$ p Annum for Chirurgery." ${ }^{3}$ Seven years afterwards Woodall still kept his post and salary, though his $£ 20$ allowance for "Chirurgery medicyns" was stopped, "and he is to have allowance hereafter for Chirurgery medicyns as by his bill shall appeare to arise and amount to." In the following year, on 21 June 1627, Woodall was given his notice: "Item wee doe order that John Woodhall the Chirurgion shall have twentye Poundes and Ten shillings paid unto him by the Receviour of the Hospitall for arrerayes of twoe yeres and three quarters of a yere to be ended at Midsomer next, And that henceforth noe setled Chirurgion shall be putt upon the House." Evidently Woodall, "late Chirurgeon of the Hospitall," handed in a petition to the Assembly at the beginning of 1628 , as on 25 February 1628 the governors refused to alter their previous order, "nor further relieve him." 44

Plurality of posts at hospitals in Woodall's day was not unusual, but to have fitted them in, as Woodall did, with all his other activities (Barber-Surgeon, Surgeon General, and so on) required a considerable capacity for planning and organization.

Sir Norman Moore's account of Woodall's career describes how, in the earlier part of his life, he gained much first-hand knowledge at home and abroad of making plague medicines and treating people with them. ${ }^{45}$ It is of special interest, therefore, that he left instructions in his will for the disposal of the aurum vitae medicine or antidote which he invented against the plague. Just as Francis Anthony's famous aurum potabile nostrum was marketed by his son Dr. John Anthony (even being sent, via Col. Henry Ashton, to Tsar Michael in Russia), ${ }^{46}$ so too it is likely that most of the profits went to Woodall's son Thomas. It was chiefly used during the 1638 plague in England, and five years later Woodall was dead. The relevant passage in Woodall's will is worth quoting. Woodall leaves to Thomas his "stills furnaces morters pestles and all my

\footnotetext{
${ }^{42} \mathrm{~A}$ brief history of the founding of the hospital is included in William Haig Brown, Charterhouse past and present, Godalming, H. Stedman, 1879. "Margaret Woodhal", the god-daughter mentioned by Sutton in his will of 1611 , may have been John Woodall's eldest daughter (p. 81).

${ }^{43}$ Charterhouse Muniments: Assembly orders, f. 34, 19 July 1614; and f. 136, 28 June 1619, respectively.

4 (a) Ibid., f. 192, 6 July 1626; f. 203, 21 June 1627; and f. 215, 25 February 1627/8, respectively. (b) See also my paper, 'Some of Arthur Dee's associations before visiting Russia clarified, including two letters from Sir Theodore Mayerne', Ambix, March 1979, 26: 3-4.

4s $D N B$, vol. 62, p. 382.

46 J. H. Appleby, 'Dr. Arthur Dee: merchant and litigant', Slavonic and E. European Rev., January 1979, 57: 55 .
} 


\section{New light on John Woodall, surgeon and adventurer}

gally potts and glasses whatsoever," and urges that,

... forasmuch as by Gods blessinge and favour upon my experience and endeavours I have invented a precious secrett for the safe curinge of the plague small poxe and divers other contagious diseases which secrett I have ymparted and given to my said sonne Thomas and not to any of the rest of his brethren That therefore he faile not every yeere yearely during his and theire lives freely to give to each of his said brethren some of the medicine vizt to his eldest brother requiringe the same each yeare one ounce of the same true antidote being truly and fully prepared wth the due quantity of truly and fully prepared gold And to his younger brother also requiringe the same one ounce and a halfe of the said medicine or antidote in all respects to be truly fully and duly prepared begynninge to deliver the first one ounce and a halfe in the first yeare of his said brother Richards practise in surgery or phisick and soe to continue yearely duringe the ioynt natural lives of my said sonns Thomas and Richard and that willingly without any grudginge or repyninge Item my further iniunction to my said sonne Thomas Woodall in regard of the publique good concerninge the foresaid medicine or antidote wch is called Aurum vitae is that he be ever myndfull that the aforesaid secrett dye nott wth him but if that God doe not lend him a sonne wch may be of capacity to make use thereof That when he faile not to ympart it to one of his said brothers wch he please, but I rather wishe it to Richard for that he is entred into the profession of surgery already In the meane tyme I streightly charge him to keepe it from being made comon. ...47

At the end of the second edition of The surgeons mate, published in 1639, Woodall informs the reader that since the publication of the first edition (in which he had promised to describe all the "Cordials, Antidotes, and other the Compositions" mentioned in the work), the Pharmacopoeia Londinensis, in which most of the medicines he had set down were incorporated, had been "hasted to the Press" (on 7 December 1618) aut nunc aut nunquam, thereby preventing him from adding a description of his aurum vitae antidote. Nevertheless he, and "he hopeth his Posteritie after him," would make and sell it to any person, "at such reasonable rates as no private man can afford to make it so cheape, although he knew the worke." 48 This edition contains, as an epilogue to Woodall's treatise on the plague, a full account of his "Cordiall Powder made of Gold" which will keep for seven years or longer and may be taken in very small (specified) doses by young and old alike. Unlike other "Minerall Diaphoretics" which operate in two to three ways simultaneously (by sweat, vomit, or purge), the aurum vitae medicine is only sudorific, should be taken along with some mithridate or posset, and cures the plague as well as any contagious fevers or agues. Having given a full description of the course of treatment and manner of administering the medicine, he attaches copies of certificates of cures performed with it at Northampton and London during the 1637-8 plague. The mayor and justices of Northampton certified that in the summer of 1637 Woodall sent William Wyly, a Northampton surgeon, the antidote as pills, with printed directions for their use, and that by its administration the lives of fifteen plague victims were preserved. This is confirmed in an appended letter from Wyly to Woodall.

The second certificate is dated 6 October 1638 and signed by "the Justices, Ministers and other the Officers of the Parish of S. Margaret Westminster, as it was by them presented to the Right Honourable, Henry, Earle of Manchester, Lord Privy Seal; Etc. which by his Lordship was presented to the rest of his Majesties most Honourable Privy Council." Woodall, it reads, "a learned, judicial, and expert man,

\footnotetext{
${ }^{47}$ Op. cit., note 4 above.

48 Woodall, op. cit., note 9 above, p. 376 ('To the Reader').
} 


\section{John H. Appleby}

and without one penny recompence for the same," supplied the officers of the parish with the antidote pills at the end of August 1638. All of the sixty victims who were thus treated for the plague, fever, smallpox, agues, and other contagious diseases fully recovered, so that the witnesses could not "doe less than publish the great skill, judgment and charity of the said Iohn Woodall." 49 How desperate the plague really was is born out by a Privy Council Register entry for July 1638 depicting the pestilence in St. Margaret's parish, Westminster, where, because of the neglect and abuses of the justices of peace and the high burgesses, thirty-five houses had been shut up, pesthouses improperly sealed off, and there was consequently risk of the infection spreading. As a result, drastic measures were adopted and Woodall's antidote proved its efficacy. ${ }^{50}$ What eventually happened to the antidote is not known, though one can surmise that the secret method of making it, imparted by Woodall to his son Thomas (appointed surgeon at St. Bartholomew's in 1661), died with him when, as Samuel Pepys twice relates, "Tom Woodall, the known chyrurgeon" was killed in a drunken quarrel with a Frenchman at Somerset House in February/March 1667. ${ }^{31}$ He was only fifty years old.

With regard to Woodall's aurum vitae antidote, it is important not to lose sight of his interest in and knowledge of alchemy and chemical medicines. Professor Debus was the first writer on Woodall to appreciate this aspect fully. He writes: "It is in The Surgions Mate also that we see the impact of Woodall's work that has been avoided in most recent accounts by medical historians. Many Elizabethan surgeons had been Paracelsians only to the extent that they had welcomed the new classical remedies. John Woodall went further, having a real interest in Paracelsian theory as well. It is easy to show the influence of Paracelsian remedies in his book..." He emphasizes Woodall's belief that all "Chirurgions ought to be versed in ... the Chymick Art, or the Art of Alchymie," and adds that it was for this reason that he included in the 1617 edition a 78-page section on alchemy, expanded in the second edition with an additional twelve-page essay entitled "Certain Fragments concerning Chirurgerie and Alchymie."'s2

From his will one can see that Woodall died possessed of considerable real estate, mostly situated in the Bishopsgate area of the City of London. Among this property was the house where he lived in Broad Street, leased to him by Sir John Robartes (1606-1685), ${ }^{53}$ and he also acquired an advowson at All Saints, the parish church of Iden, four miles north of Rye in East Sussex, which went to his son John, who later

\footnotetext{
49 Ibid., pp. 367-375. An exceedingly rare pamphlet by Woodall on his nostrum was published separately: The cure of the plague by an antidote called Aurum Vitae, London, Nicholas Bourne, 1640, $12 \mathrm{pp}$. (There is one copy in the British Library, and another in the Wellcome Institute Library.)

so PRO: Privy Council Register, P.C. 2/49, pp. 351-352 (29 July 1638).

${ }^{31}$ H. B. Wheatley (editor), The diary of Samuel Pepys, London, G. Bell, 1923, vol. 6, pp. 192, 193.

32 Allen G. Debus, 'John Woodall, Paracelsian surgeon', Ambix, October 1962, 10: $110,111-112$. For a counter-argument cf. Margaret Pelling and Charles Webster, 'Medical practitioners', in Charles Webster (editor), Health, medicine and mortality in the sixteenth century, Cambridge University Press, 1979, p. 204.

${ }^{33}$ DNB, vol. 48, p. 339. Guildhall Library 'Citizens of London, 1641-1643 - the most wealthy inhabitants of London in 1640', transcribed from PRO MSS. by Rev. T. C. Dale, lists Woodall in the Broad Street Ward (p. 26).
} 


\section{New light on John Woodall, surgeon and adventurer}

became rector of the parish. ${ }^{54}$

It was said earlier that when Woodall was made the East India Company's Surgeon General in 1612, he had already invested a substantial portion of his money in foreign enterprises. Besides his adventures in the Company, the range of his commitments is suggested by a document to which reference has already been made, as showing that he was an army surgeon in 1612. Headed "Members of the Drapers' Company who were concerned with the Companies of Virginia, Somers Isles, and North-West Passage, 1589-1625," the list carries only six names, including Woodall's, who is mentioned as subscribing $£ 37$ to the Drapers, with the editor's qualification that these "incorporators were very improbably freemen, although the names are on the list of the Company." Woodall's name also appears among four other names of incorporators of the Somers Isles Company who may have been members of the Drapers' Company. ${ }^{55}$ Woodall had several other links with the Drapers. One of the two overseers of his will was Timothy Cartwright, who was a Warden of the Company from 1641 to 1642 . Then there was Richard Edwards, with whom Woodall traded. Edwards, Warden four times and Master of the Drapers from 1631 to 1632, an incorporator of the Somers Isles Company, and a member of the East India, NorthWest Passage, and the Turkey Companies, ${ }^{56}$ is said to have introduced the use of coffee into England. ${ }^{57} \mathrm{~A}$ case about a small amount of money, but extending from 1624 to 1633, involved Woodall in Chancery proceedings against Richard Edwards, who also took up his suit against Woodall in the courts of the King's Bench and Exchequer Chamber. ${ }^{58}$

Much more light is shed on Woodall's commercial commitment by a letter which he wrote in October 1613 to William Trumbull, Clerk of the Council. Apart from some interesting news about Sir Henry Middleton's sixth voyage to the Indies and attempts to explore a North-West passage (the North-West Passage had been discovered the year before), Woodall mentions "so great mortality amongst our men in the ships coming from the East Indies that it is strange," and that four ships, "very rich laden came from the E. Indies, as well as 8 more." However, the main purport of the letter was to inform his correspondent about plantations in Virginia and Bermuda. Here it is relevant to point out that it was from the East India Company's dock at Blackwall that the first emigrants had sailed in December 1606 to found a permanent English colony at Jamestown. Woodall writes: "Our plantation in Virginia stands hopeful many ways. For victuals they have now the things they formerly wanted, being well furnished wth cows, goats, hens, swine, etc. but they are not above 400 strong. They are well planted concerning their dwellings and only want 1000 men, which I hope to

\footnotetext{
34 Allegations for marriage licenses issued from the Faculty Office of the Archbishop of Canterbury at London, 1543 to 1869 , London, Harleian Society, 1886, p. 105.

ss Johnson, op. cit., note 20 above, vol. 3 (1922), pp. 86, 89. Among these names on the first list is Woodall's associate, Captain James Martin, who had commanded a ship in Drake's voyage of 1585-6, and George Yeardley, subsequently a Governor of Virginia.

36 Ibid., Cartwright (pp. 136, 239-240, 420); Edwards (pp. 59, 420, 445, 457).

37 Alexander Brown, Genesis of the United States, 2 vols., London, Heinemann, 1890, vol. 2, p. 884.

s8 PRO: Chancery Proceedings, Bills and Answers, C2 Chas i/W.53/2 and W.57/67.
} 
see supplied in the spring, for there is a good course in hand to help it substantially." 59

Moore remarks that Woodall subscribed $£ 37$ 10s. 0d. to the Virginia Company, though he is said not to have paid it. However, on Woodall's own cognizance we learn that his estate in the colony was worth $£ 1,000$ at a conservative estimate. ${ }^{60} \mathrm{His}$ export of cattle to the colony as an adventurer in the Company is covered by its records, from 1621 onwards. In April 1623 his servant Christopher Best wrote in a letter to Woodall from Virginia that several of his cattle had died because of a "generall mortalitie" and one of his calves had been shot. On 20 September that year Woodall, Capt. James Martin, ${ }^{61}$ an Armenian named after him, Sir Thomas Wroth, Sir Samuel Argall, and four others voted for the Company to surrender its charter. ${ }^{62}$ They must have been voicing the feelings of many traders who were dissatisfied with the way the Company was run. Because of the quarrels of rival factors at home and abroad (in Virginia the feuds were compared to those of the Guelfs and Ghibellines of Italy, and their meetings declared to be cockpits rather than courts), the Company was summoned before the Privy Council in 1623 to answer a charge of loose and inefficient administration. This resulted on 24 July 1624 in an action Quo Warranto (a writ issued by the King's Bench Division calling on the Company to show by what warrant it exercised its offices or prerogatives), whereby the whole control of the colony was transferred to the Crown and the Company reduced to the position of a mere trading society, dependent on royalty for its position and privileges. ${ }^{63}$

As a subscriber to tobacco stock, Woodall was appointed in 1623 to a committee of the Virginia Company for importing Spanish tobacco. ${ }^{64}$ The Port Books of the Port of London indicate that he imported $150 \mathrm{lb}$. of tobacco in 1626 and 3,250 lb. in April $1634,{ }^{65}$ while a person, who was probably his eldest son John, obtained a licence to go to Virginia on 4 July 1634.66

Of course, other doctors such as Theodore Goulston and Thomas Winston, of the College of Physicians, side by side with such inveterate antagonists of the College as Francis Anthony and Leonard Poe, were active members of the Virginia Company. ${ }^{67}$ Dr. Keevil's biography of Goulston is particularly informative about his financial and

\footnotetext{
59 Historical Manuscripts Commission, Marquess of Downshire MSS., London, 1940, vol. 4, pp. 215216, John Woodall to William Trumbull, London, 7 October 1613. For Trumbull, see DNB, vol. 57, p. 264.

${ }^{60}$ PRO: Acts of the Privy Council of England, London, 1964, pp. 202-203 (P.C. 2/44). There is a passing reference in the same source to profits Woodall derived from the sale of honey from beehives on his Virginian plantations.

${ }^{61}$ See note 55 above.

${ }^{62}$ Susan Myra Kingsbury (editor), The records of the Virginia Company of London, Washington: (a) 1900, vol. 1, p. 578; (b) 1933, vol. 3, p. 649; (c) 1935, vol. 4, p. 238; (d) W. N. Sainsbury (ed.), op. cit., note 22 above, 1513-1616, p. 53; (e) $D N B$, vol. 2, p. 78 (Argall); and vol. 63, p. 165 (Wroth).

${ }^{63}$ Johnson, op. cit., note 20 above, vol. 3 (1922), p. 65.

${ }^{64}$ Kingsbury (ed.), op. cit., note 62 above, vol. 2, p. 388.

6s PRO: (a) E. 190/31, 3, f. 62 (20 May 1626); (b) E. 190/38/5, f. 82 (18 April 1634).

66 PRO: E. 157, Licences to go beyond the seas (4 July 1634).

${ }^{67}$ Kingsbury (ed.), op. cit., note 62 above, passim. Peter Turner, Sir Walter Raleigh's physician, Thomas Hood (who sailed round the world with Drake), Thomas Lodge, William Turner, and Peter Maunsell were more physicians who subscribed in the Company: see Wyndham R. Blanton, Medicine in Virginia in the seventeenth century, Richmond, Va., Medical Society of Virgina, 1930, pp. 4-5.
} 


\section{New light on John Woodall, surgeon and adventurer}

professional participation in the affairs of the Company (thus presenting a useful parallel with Woodall's), as well as providing revealing details, from its Annals, of the College of Physician's discussions of the medical aspects of tobacco imported to England from Virginian plantations. ${ }^{68}$

Woodall had embarked on his commercial speculations even earlier as a planter and shareholder in Bermuda. Although the group of islands had been visited by Spaniards in 1515, they were first settled in 1609 as an unscheduled part of the original attempt to colonize Virginia. Known at first as Virginiola, but then by their original name of Bermudas (after the Spaniard Juan de Bermudez) or the Somers/Summer Islands (after Sir George Somers), they were visited by a representative of the Virginia Company in 1612 and finally leased to the Somers' Islands Company, which was set up in 1615.69 Woodall's shares in this Company are recorded in the transactions of the Virginia Company, ${ }^{70}$ but he himself, in his 1613 letter to William Trumbull, indicates the actual degree of his participation:

The plantation in the Barmoothas goeth on exceeding well and yieldeth good profit. I have a hundredth part of the whole island. It hath already cost $5000 \mathrm{l}$. the planting and yieldeth $4000 \mathrm{l}$. back and we have our whole stock untouched. We have 100 men dwelling there and are sending 60 more. They have planted 14 pieces or ordinance in places of best advantage. In this ship they carry great store of powder and shot. Within a month we intend to send 200 more men. If we are 500 strong then all Spain could not annoy us by reason of the natural strength of the place, and the country yieldeth sufficient food and fresh water. We doubt nothing it will prove a very rich place. It hath yielded in ambergreece to the value of $3000 \mathrm{l}$. and more. If we had good divers we might have more store."1

Sufficient material has been presented so far to convey how wide-ranging were Woodall's commitments as an adventurer, but it would be misleading to overlook the misfortunes, imprisonment, and protracted litigation which accompanied many of these interests. Woodall's first confinement in prison occurred in the third week of January 1625 when, sentenced by the Lord Steward, he was incarcerated - probably in the Fleet Prison - for "serving process upon Sir Thomas Merry, his Majesty's servant in ordinary." When the governor of the East India Company applied for his release, the Lord Steward asked "if no other man could serve the Company's turn but that one," declaring "how insufferable a thing it is that the King's servants be served with process in the King's house." Woodall acknowledged on 31 January his debt to the Company in procuring his liberty. Evidently this was only temporary, however, for a fortnight later he was remanded to prison again by the Lord Steward, "to the hazard of his utter undoing." Representing him, Sir Humphrey Handford asked the Company to obtain Woodall's freedom, adding that the last imprisonment had been contrived by some of the prisoner's private enemies. The Court expressed concern but willed that he should "use his own best means first"; then, if not successful, they would move the Lord Steward to release him. Presumably he was soon freed. ${ }^{22}$

68 J. J. Keevil, 'Theodore Goulston, M.D., F.R.C.P., 1574-1632', Bull. Hist. Med., 1953, 27: $205-208$.

${ }^{69} D N B$, vol. 21, pp. 64-65, and vol. 53, p. 220.

${ }^{70}$ Op. cit., note 62 (c) above, pp. 20,81. See Woodall's name on the Company's Charter granted 29 June 1615. Brown, op. cit., note 57 above, p. 770.

$"$ Op. cit., note 59 above.

72 E. B. Sainsbury (ed.), op. cit., note 23 above, 1625-1629, pp. 14, 16, $20,34$. 
Fortunately Town Depositions at the Public Record Office illustrate the other side of this picture - the case brought by Sir Thomas Merry against Woodall in 1625. (Depositions are basically a class of documentation entailing the sworn statements of witnesses in reply to "Interrogatories", a series of written queries formulated first on behalf of a plaintiff, and then of a defendant, in actions subsequently heard in the courts.) The present case revolves around the estate and the custody of property belonging to John Powntys (or Pountis) employed about 1618 by the Company of Sturgeon Fishers in London and appointed Vice-Admiral of Virginia in 1621, who had died on his way home from Virginia, at Falmouth, in June 1624. Before this last voyage, Powntys had made his will, leaving $£ 5$ apiece and his highly valuable books to Woodall and Dr. Patrick Saunders, and appointing his cousin Merry his executor. ${ }^{73}$ He had then locked up three rooms of his house in the London parish of St. Martin Outwich and handed the keys to Woodall - hence the legal proceedings taken by his executor Merry against Woodall to determine the extent of his custodial responsibilities for the late Powntys's goods, an issue complicated by various factors outside Woodall's control, which it would require a disproportionate amount of space to elucidate. Certain aspects of this exceptionally interesting case (the extremely rare and precious books, manuscripts, jewels, and mechanical instruments which Powntys had acquired from the famous Dr. John Dee) have already been dealt with. ${ }^{74}$ The depositions reveal a great profusion of detail about the cattle and medicines that Woodall used to send to Virginia. For instance, George Lile, a surgeon who had been apprenticed to Woodall and acted as his agent in Virginia, had sold Powntys twentytwo head of cattle. Also, according to Christopher Best, Woodall's servant, his master sent the following items to Powntys in Virginia on the ship Charles in July 1621: 48 firkins and 24 kegs of salt; a new suit of clothes valued at $£ 9$ and a night cap "wrought wth gold"; 2 rundlets of aqua vitae and 1 tun of vinegar (both worth three times their price in Virginia); 1 copper still ( $£ 310$ s. $0 d$.) plus a parcel of copper plates $(£ 1)$; and 1 ounce of laudanum (valued at $£ 315 s$. $0 d$.). Another informative witness was Henry Boone, a Barber-Surgeon (free in 1622) who had been apprenticed to his "uncle" Woodall for eight years and who replaced him as the East India Company's chief surgeon in 1643. He testified that after Powntys's last voyage to Virginia he, as Woodall's apprentice, knew that,

the said defendant then sent divers supplies unto the said Pounties, of meale and divers phisicall and chirurgicall medicines with divers of the merchandizing affaires, which the said Pountes from tyme to tyme received ... And defendant likewise sent to the said John Pounties in Virginia a man whoe by profession was a Chirurgion, whom the defendant furnished with a Chirurgions chest and many other necessaries for his owne provision both in victualles, stronge waters, and other thinges, and stood the defendant in a great deale of mony. And he further saith that during the tyme of the aboarde of the said John Pountis in Virginia, there went fewe shipps thither wherein the said defendant did not sent severell supplies unto the said John Pountis. ... ${ }^{\text {s }}$

\footnotetext{
${ }^{73}$ PRO: PCC 64 Byrde, will of John Pountes [sic], Citizen and Clothworker of London, made 28 December 1618 , proved 18 June 1624 .

${ }^{74}$ See my paper, 'Arthur Dee and Johannes Bánfi Hunyades: further information on their alchemical and professional activities', Ambix, 1977, 24: 97-98; also, Appleby, op. cit., note 44 (b) above, pp. 2, 4.

7s PRO: Town Depositions C24/507, Part 2; C24/511, Part 1/142; C24/515/94; and C24/521, Part 2/46; January 1624 to May 1625.
} 


\section{New light on John Woodall, surgeon and adventurer}

In other cases associated with the Virginia Company, Woodall was called on to testify without being directly involved himself. Thus, in 1621 he twice gave evidence in a legal case, with Captain John Bargrave as plaintiff and Sir Thomas Smyth and others as defendants. The issue at stake was the state of part of a consignment of $11,000 \mathrm{lb}$. of tobacco that Bargrave had bought from the Virginia Company. Woodall deposed that he knew the plaintiff purchased 1,700 lb. of tobacco from the Company, but not when; that he was to pay $£ 8$ for it; that he believed the plaintiff fetched the $1,700 \mathrm{lb}$. away from the Company; and that he agreed it had deteriorated in stock. He also claimed knowledge of the original agreement drawn up between the two parties in August 1618, as he had seen the man who wrote the bond. ${ }^{76}$ At another case concerning the goods and livestock of Sir Thomas Gates, late Governor of Virginia, and left by him there at the time of his death, the 68-year-old Woodall answered on 21 June 1638 the interrogatories with the statement that he knew Gates before he went to Virginia, but as he was in no way acquainted with or privy to his estate he was unable to depose. ${ }^{77}$

Woodall, however, was deeply involved in very acrimonious, protracted, and costly legal proceedings. Through his associations with Sir Samuel Argall, a previous Deputy Governor of Virginia, he secured the option of purchasing Argall's estate from the legatees. Argall, who died at sea in 1626, "lawfully possessed in ffee of divers lands lying in Virginia and being likewise possessed of diverse kine and bulls in Virginia and of the surcease of them to the number of three hundred of cattle or thereaboute [since greatly increased] ...", bequeathed all his "goods lands chattel and estate in Virginia" to his daughter Ann, wife of Samuel Perivall, a chandler. Woodall, an "antient debenturer and planter in Virginia", complained in his Chancery Proceedings' bill against the Perivalls that, whereas he had paid them "a full and valuable consideracion of ready mony" in exchange for this legacy, the couple had deliberately defrauded him of his rightful property. He had sent, he explained, numerous servants to Virginia to manage the property and livestock for him, and had procured Privy Council letters to the Governor and Council of Virginia, from whom he obtained a "sentence" allowing him to take possession of his estate, whereupon part of it had immediately been made over to this assignee. During his lifetime Argall, when he "left the Government there", had placed this, his estate, cattle, and goods, in trust to several Virginian planters in order "to give them milke and succor in their necessities." (Here Woodall gives a specific breakdown of the numbers and types of the goods and livestock, along with the names of individual merchants.) But at the time of Argall's death many of those holding his property and goods in trust had already died or left the management of the property to others. Several of them, Abraham Perry and Captain Samuel Matthews in particular, now refused to surrender the property or to provide an account of their holdings. Furthermore, Woodall added, Samuel and Ann Perivall did "combyne and confederate" with those in Virginia, claiming that he had "not made full payment". Woodall therefore requested the judge to subpoena Samuel Perivall to answer the charges in the High Court of

\footnotetext{
76 Ibid., (a) C24/473; (b) C24/478/74

${ }^{n} \mathrm{Op}$. cit., note 3 above.
} 


\section{John H. Appleby}

Chancery and to produce full details, with bonds of transactions and payments. Soon after, on 3 July 1631, Samuel Perivall denied all charges in his answer, maintaining that he was unable to declare the exact extent of the estate and stock. ${ }^{88}$

Numerous entries in the Acts of the Privy Council, from 1631 to 1639, show all too plainly the tenacity and perseverance needed by Woodall to secure his legitimate property in Virginia - both the Argall estate and his other holdings. Thus, in July 1634 the Privy Council addressed yet another letter on Woodall's behalf to the Governor and Council of Virginia, asking them to examine many of Woodall's servants, who were converting his estate ("which he conceiveth to be the value of $a$ thousand poundes at the least") for their own use and refusing to account for their actions. With renewed urgency, the Privy Council repeated its request two years later, calling at the same time for John Convers, Woodall's new agent, to be established on his estate, for Woodall to receive sole profit from the honey made by his bees and, generally, to expedite matters "since the Poore Man hath not hitherto receaved that effect and Justice Wee expected." 79

Whether for financial or other reasons, Woodall was in dire straits on 16 March 1636, when certain naval officers presented a petition to the Lords of the Admiralty asking that if Woodall, "being by the Lords order a prisoner in the Fleet," was not to be released, then they should be allowed to undertake the duty he normally performed and for which he received $£ 50$ imprest (money advanced for some state commission) the appointment of surgeons "for the ships employed in the present service". His release, however, followed on 27 March. ${ }^{80}$

The Board of the Star Chamber contacted the Governor of Virginia, Sir John Harvey, on Woodall's behalf in 1637, enclosing his petition and soliciting the Governor to do justice "against such persons as had prediudiced him in his Estate there, or detayned any parte thereof," and licensing Woodall to transport and sell his cattle "to such other English Plantations thereaboutes as may be more advantagious unto him." A further letter from Whitehall in July 1638 supported Woodall's claims to his land and to the "Estate of Sir Samuel Argall which he purchased as in respect of his own adventure being a thousand pounds laid out many yeares since." Three months later Woodall's complaint, now centred upon Captain Samuel Matthews, a councillor in Virginia and a commissioner there, having been argued by counsel before the Board of the Inner Star Chamber, was referred to a sub-committee for foreign plantations, and the same Board, having heard the allegations by both parties, recommended in November 1638 the Governor and Council of Virginia to restore all the cattle and goods adjudged to Woodall. The arrival, in November 1639, of Sir Francis Wyatt as

73 (a) PRO: Chancery Proceedings, C2 Chas i/W.48.20: Woodall's bill and Samuel Perivall's answer (3 July 1631); (b) Acts of the Privy council of England (1630 June-1631 June), London, 1964. pp. 405-406 (P.C. 2/41); (c) Argall's will: PRO. Prob. 11/169, 69, made 6 April 1625 and proved I May 1626. (d) Argall's account of a voyage to Virginia and an exploratory voyage from there to Bermuda (in 1610) are given in Purchas his pilgrimes, London, 1625, vol. 4, pp. 1758-1762, 1764-1765.

As late as on 25 June 1641, the Perivalls petitioned the House of Commons for the property from Woodall. Brown, op. cit., note 57 above, p. 816.

${ }^{79}$ Op. cit., note 78 (b) above, pp. 202-203 (P.C. 2/44); pp. 213-214 (P.C. 2/46).

${ }^{20}$ Calendar of state papers. Domestic. Charles I (1635-66), London, 1866, vol. 9, pp. 299, 330. 
the new Governor of Virginia entailed a re-examination of the evidence, but the Privy Council asked him, if he endorsed (as they thought he should) the previous proceedings whereby Matthews' complaint had been proved "causeless", to ensure that the latter paid Woodall any additional costs and damages, and that the cattle in question remained in Woodall's hands. ${ }^{81}$

Woodall found himself involved in two further legal cases connected with Bermuda, but he appears to have testified at neither. The evidence of the first, and more important, was heard in August 1638 with Woodall defending an action brought by Edward Ellesden. The case concerned goods sent to Bermuda by Ellesden in Woodall's care. Woodall sent William Capps, his agent, in charge of Ellesden's goods because Capps had formerly been Ellesden's employee. Ellesden seems to have been in Bermuda at the time, and there was a dispute between him and Woodall which resulted in Woodall having Ellesden arrested in Bermuda until he had rendered an account of this business to the Governor. ${ }^{82}$

The second action was brought by Woodall and six other merchants against Charles Harris and Benjamin Gooding. Its sequel, with the roles reversed, was heard between 18 October 1639 and 11 April 1640. A merchant, Richard Laycroft, commissioned by Woodall and the others as their agent and factor in Bermuda to take up their several crops of tobacco and to let their land for them, used to send over tobacco in several ships to England for sale. Laycroft dispatched twenty-two hogsheads and some rolls of tobacco from Bermuda in December and January 1637/8, and the case hinged on these and the rates at which they were sold in London during the following spring. ${ }^{83}$

This essay makes no claims to exhaust the reservoir of unexplored material about John Woodall, but an attempt has been made to show the complexities and importance of his business interests. They meant far more to him than a profitable sideline and formed an integral part of his career. A balanced assessment of the man must take them into adequate consideration.

\section{SUMMARY}

The aim of this paper has been to highlight documents which, 337 years after his death, provide fresh insight into the life and career of John Woodall, the first Surgeon General of the East India Company. Main emphasis is given to Woodall's activities as a shareholder in the East India, Virginia, and Somers' Islands Companies, showing that these were a far more extensive and important part of his life than realized, involving him in protracted litigation which led to his imprisonment and brought him to the brink of financial ruin. At the same time, the discovery of Woodall's will, and the examination of other primary sources of information, reveal many new facts about his family, his controversial associations with the Barber Surgeons, his duties as surgeon to four London hospitals, and the surgeons' chests and other medical supplies

\footnotetext{
${ }^{81}$ Op. cit., note 78 (b) above: p. 224 (P.C. 2/48); pp. 237 and 244-246 (P.C. 2/49); pp. $261-262$ (P.C. 2/50).

82 PRO: Town Depositions C24/631/23, Edward Ellesden v. John Woodall, August 1638.

${ }^{83}$ Ibid., C24/629/46 and C24/643/80.
} 


\section{John H. Appleby}

he provided for the East India Company's ships and English colonists. The instructions Woodall left in his will for preserving his secret aurum vitae plague antidote are seen to have been justified by the nostrum's attested success in curing victims at Northampton and Westminster during the outbreak of the plague in 1637-38. 